\title{
Why Donald Trump Should Be a Fervent Advocate of Using Ranked-Choice Voting in 2024
}

Jonathan Cervas, Carnegie Mellon University, USA

Bernard Grofman, University of California Irvine, USA

ABSTRACT This article builds on work by Devine and Kopko (2021) and Lacy and Burden (1999) who estimated a probit model of candidate choice from nationally representative survey data to determine the second choice of third-party voters. Using this model on 2020 election data, we show that the Libertarian candidate Jo Jorgenson probably cost Donald Trump victory in at least two states: Arizona and Georgia. Additionally, the popular-vote margin enjoyed by Joe Biden could have been between 260,000 and 525,000 fewer votes, using conservative estimates. The motivation for this article is to provide contrary evidence for two main misconceptions. First, that third-party candidates are "spoiling" elections for the Democrats. Our evidence clearly shows that third parties have the potential to hurt either of the two main parties; however, in 2020, it was Donald Trump who was hurt the most, although not consequentially. Second, some reformers believe that ranked-choice voting benefits the Democrats; again, we show that-all else being equal-in the 2020 presidential election, it was the Republicans who would have benefited by the change in rules because the majority of third-party votes went to the Libertarian candidate, whose voters prefer Republicans over Democrats 60\% to $32 \%$.

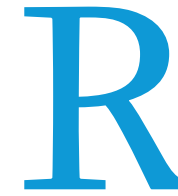

eforms to address perceived deficiencies in American elections have included changes to primary rules (Grose 2020; McGhee et al. 2014), redistricting reform (Grofman and Cervas 2018; Nagle 2019; Saxon 2020), and revisions to election registration and balloting rules (Burden et al. 2014), among others (Wang et al. 2021). One particular voting reform that has generated significant recent interest is the instant runoff election, commonly referred to as ranked-choice voting (RCV). ${ }^{1}$ This electoral reform was recently implemented in Maine and was adopted in Alaska for federal

Jonathan Cervas (D) is a postdoctoral teaching fellow at Carnegie Mellon University. He can be reached at cervas@cmu.edu.

Bernard Grofman (D) is Distinguished Professor of Political Science and Jack

W. Peltason Chair of Democracy Studies at the University of California, Irvine. He can be reached atbgrofman@uci.edu. elections beginning in $2022 .^{2}$ It also is being used in various cities, including city council elections in San Francisco and the New York City mayoral race. RCV is purported to have several positive characteristics, including reduction in negative campaigning and a greater likelihood of electing moderate candidates. It almost certainly leads to the encouragement of more candidates, including women and racial minorities (John, Smith, and Zack 2018). One indisputable advantage of RCV is the ability it gives a voter to support a candidate with a lesser chance of winning while still providing support for a candidate with a higher probability of victory by including both in the voter's ranking.

In the United States, the most ardent supporters of RCV tend to be liberal reformers, who call to mind examples of situations in which RCV would have benefited Democrats. Because this reform is being pushed by the political left, it is seen-incorrectly-as being biased against Republicans; RCV's opponents tend to be 
Republicans. For example, an unsuccessful lawsuit in Maine brought by members of the Republican Party asked the court to find RCV unconstitutional (United States District Court District of Maine 2018).

This article provides evidence of why, in contemporary presidential politics, RCV should be attractive to Republicans. However, the bottom line is simple: a priori, there is no reason to believe that RCV has any partisan or ideological bias, even if it congressional district. Poliquin received more first-place votes than Golden, and his failure to secure the seat infuriated him, who called the outcome the "biggest voter rip-off in Maine history" (Maine Examiner 2019). Poliquin then unsuccessfully sued the secretary of state, claiming he won the "constitutional' oneperson, one-vote first-choice election" (Pathé 2018).

Whereas we agree with Wolfinger's famous observation (quoted in Wuffle 1986) that "data is the plural of anecdote," it also is

\section{...the bottom line is simple: a priori, there is no reason to believe that $R C V$ has any partisan or ideological bias, even if it might be shown to favor (relative to a simple plurality) one party or another in particular circumstances.}

might be shown to favor (relative to a simple plurality) one party or another in particular circumstances. ${ }^{3}$

The role of minor-party candidates as potential "spoilers" has long been a topic of concern. That concern became more salient after Ralph Nader's role in denying Al Gore the 2000 victory in Florida, thereby denying him the presidency. As a consequence of Nader's taking votes from the Democratic candidate, much of the subsequent outcry has been about Green Party candidates costing Democrats votes. In 2016, there were assertions that Jill Stein, the 2016 Green Party candidate, was a spoiler for Hillary Clinton (see Herron and Lewis 2007; Magee 2003; Nguyen 2016; and the following discussion). However, even if minor-party candidates did not change the presidential election outcome in 2016 (Devine and Kopko 2016, 2021), can we state the same for 2020? Unlike the election in 2016, the 2020 election did not exhibit an Electoral College inversion of the popular vote (Cervas and Grofman 2019). Nonetheless, despite Joe Biden having won the national popular vote by more than seven million votes, the outcome was very close in many states-as it was in 2016-including the pivotal states of Michigan, Pennsylvania, and Wisconsin. Indeed, with only a few thousand changes in votes, Trump would have been reelected in 2020. Moreover, as we demonstrate, there was an even greater scope for minor-party candidates to have affected the election outcome in 2020 than was the case in 2016.

After reviewing work on the effects of minor-party candidates in 2016 and then examining the probable effects of minority-party candidacies in 2020 under current election rules, we consider what might have happened in 2020 had presidential voting taken place under RCV. On the one hand, this reform generally is touted in terms of its impact in promoting minor parties by allowing voters to cast votes for the candidates of minor parties without harming the chances of major-party candidates who would be a voter's second choice. On the other hand, RCV also can be thought of as an "anti-spoiler" reform that reduces the likely impact of minorparty candidates on election outcomes. Thus, we have a pro-RCV coalition in which minor-party supporters tend to favor this reform because it presents a way to affect the two-party cartel that has dominated American politics for the past $150+$ years together with major-party supporters who believe that RCV, in general, will help moderates-an advocacy especially true for Democrats concerned about spoiler votes from the left. ${ }^{4}$

Democrat support for RCV was reinforced when the Democratic candidate, Jared Golden, defeated Republican incumbent Bruce Poliquin, after multiple rounds when all candidates failed to reach $50 \%$ of the vote in the first round for the 2018 Maine second important to remember another aphorism-namely, "not all swans are white." Concluding that RCV necessarily (or even usually) can be expected to benefit Democrats is simply wrong. Based on the two most recent presidential elections and building on Devine and Kopko (2021), we show that at the presidential level, RCV actually is likely to benefit the Republican nominee.

\section{THE PRESIDENTIAL ELECTION OF 2016}

In 2016, there were two minor-party candidates who received at least a million votes: Gary Johnson, running as a Libertarian, won 4.5 million votes, and Jill Stein, running as the Green Party candidate, won 1.5 million votes. ${ }^{5}$ It is common to view Libertarians as ideologically closer to Republicans, in part because some high-profile Libertarians are former Republicans (e.g., Gary Johnson was the Republican governor of New Mexico before being the Libertarian presidential candidate in 2012 and 2016), whereas Green Party candidates are perceived as ideologically closer to Democrats because they tend to have platforms uniformly to the political left of the Democrats. ${ }^{6}$

In 2016, if Johnson's voters had instead all chosen Trump and Stein's had all chosen Clinton, Trump would have lost the popular vote by only 220,461 votes rather than the actual 2,868,686 votes. Moreover, under this strong assumption, the outcomes would have changed in four states: Trump would have won additional electors in Maine and won Minnesota, Nevada, and New Hampshire, for an additional 22 Electoral College votes. In contrast, under these assumptions, there are no additional Clinton victories. Thus, under the assumptions most favorable to minority-party impact, the absence of minority-party candidates would have significantly benefited Trump in terms of both popular vote and Electoral College seat share-but still would not have changed the outcome. However, if only Stein did not run but Johnson remained, Clinton likely would have picked up electors in at least one state: Michigan (Devine and Kopko 2021).

Nevertheless, it is unrealistic to assume that all minor-party supporters would have shifted their support to a major-party candidate if their preferred choice were not in the contest. Supporters of minor parties can exhibit negative affect toward both major parties (Abramowitz and Webster 2018), leading to abstention. Using a multinomial probit model and building on Lacy and Burden's (1999) analysis of the 1992 presidential election, Devine and Kopko (2021) estimated that about half of the minority-party supporters would not have voted if their own candidate had not been in the race. They also estimated that in 2016, among non-abstainers, about $60 \%$ of the 
Table 1

2020 Election Results in Four Pivotal States

\begin{tabular}{lcccccc} 
State & Electors & Biden (D) & Trump (R) & Biden Minus Trump & Jorgensen (L) & Hawkins (G) \\
\hline Arizona & 11 & $1,672,143$ & $1,661,686$ & 10,457 & 51,465 & 1,557 \\
\hline Georgia & 16 & $2,473,633$ & $2,461,854$ & 11,779 & 62,229 & 1,013 \\
\hline Pennsylvania & 20 & $3,458,229$ & $3,377,674$ & 80,555 & 79,380 & - \\
\hline Wisconsin & 10 & $1,630,866$ & $1,610,184$ & 20,682 & 38,491 & 1,089 \\
\hline NATIONAL ELECTORAL COLLEGE & 538 & 306 & 232 & $7,060,519$ & 0 \\
\hline
\end{tabular}

voters who ranked the Libertarian candidate, Gary Johnson, first would have ranked Trump second and about $32 \%$ to $33 \%$ would have ranked Clinton second. Similarly in 2016, they estimated that about $75 \%$ to $80 \%$ of voters who ranked the Green Party candidate Jill Stein first would have ranked Clinton second and about $20 \%$ would have ranked Trump second. We conclude that, on balance-at least vis-àvis the popular vote-minor-party candidates in 2016 hurt Trump more than they hurt Clinton.

\section{THE PRESIDENTIAL ELECTION OF 2020}

In 2020, there was again a Green Party candidate for president, Howie Hawkins, and again a Libertarian candidate, Jo Jorgensen. However, in 2020, Green Party supporters were more anxious to defeat Trump. They recognized Trump's victory as a real possibility and thus were more likely to choose to vote strategically. Hawkins failed to make the ballot in 22 states, whereas Stein was on the ballot in all but three states in 2016. Thus, the votes for the Green Party candidate were significantly fewer in 2020 than in 2016 (i.e., 405,035 versus 1,457,288).7 In contrast, Jorgensen performed substantially better in terms of raw votes, with 1,865,724 votes in 2020-although still far from the 4.5 million votes for Johnson in 2016. Distribution matters! The 2020 data for four key states are shown in table 1.

The table shows that Jorgensen's votes, in principle, could have affected the outcome in three states (i.e., Arizona, Georgia, and Wisconsin), with a combined total of 37 electors. In these states, the margin of Biden's victory was not only less than the Jorgensen vote share but also less than the Jorgensen vote share minus the vote share of Hawkins-sometimes markedly so. These are the only three states won by Biden in which the Jorgensen vote relative to Biden's vote margin is significant enough to plausibly affect the outcome. ${ }^{8}$ The 37 Electoral College votes in these three states would have been enough to change the Electoral College outcome to a tie if all three states had gone to Trump. If there had been a tie in the Electoral College, voting would have gone to Congress; with each state's delegation in the House voting as a bloc and with votes in tied state delegations not counted, Trump would have won because Republicans control more delegations in more states. We note that because of this state-based bloc-voting rule, the party that holds the majority in the House nevertheless could fail to elect its preferred presidential candidate (Foley 2020).

Also noteworthy is the potential importance of minor-party votes in Pennsylvania. If every Jorgensen voter in that state had switched to Trump, the state outcome would have been very close, with a gap of only 1,175 votes. During the certification of votes, Pennsylvania was one of the states asserted by Republicans to have irregularities, and its outcome continues to be challenged by former President Trump (as of September 2021). In light of the events of January 6, 2021, we can only imagine the furor if the outcome of the election in Pennsylvania had been this close.

Of course, positing that all of the Hawkins votes would go to Biden and that all of the Jorgensen votes would go to Trump is highly unrealistic. Nevertheless, whereas only voters know for sure how they would vote if certain candidates had not been on the ballot, plausible inferences are possible. What is likely to have happened if Jorgensen (or perhaps both Jorgensen and Hawkins) had not been on the ballot in 2020 and there was no other Libertarian candidate to replace Jorgensen?

Imagine that Hawkins remains in the race in 2020 but there is no Libertarian candidate. If we posit that the same second-preference rankings found by Devine and Kopko (2021) for 2016 apply to Libertarian voters in 2020, and we posit that half of the Libertarian voters would have abstained if their candidate had not been in the race in 2020, we now would find that no states shift in $2020 .^{9}$ Conversely, if we posit a zero rate of abstention for former Jorgensen voters, then there are two states that shift to Trump: Arizona and Georgia-and these two states would shift to Trump even if all of their Hawkins voters shifted to Biden. However, these two states still would not be enough to change the Electoral College outcome. ${ }^{10}$

We might think that these results indicate that minority-party candidates did not have any real impact in 2020, but this is much too strong a conclusion. Assuming a $50 \%$ abstention rate if there were no Libertarian option on the ballot, Trump would have gained almost 260,00o net votes. Moreover, if there had been no Libertarian candidates on the ballot but all Libertarian voters still participated, with Trump receiving $60 \%$ of their votes, Arizona and Georgia would have flipped in 2020. Trump's popular-vote loss also would have shrunk by 522,403 votes-and, importantly, Pennsylvania would have been considerably closer. ${ }^{11}$

\section{RANKED-CHOICE VOTING}

Let us ask a different but related question about the 2020 presidential election. What might have happened in 2020 had RCV been used instead of plurality? RCV asks voters to rank the candidates. Under Maine rules for RCV for federal elections (Akula, Cervas, and Goren 2020), if no candidate receives a majority of first-choice votes, then the candidate with fewest first-choice votes would have the votes on the ballots that ranked that candidate first reallocated to the voter's second choice on the ballot. The process continues in this way until one candidate has a majority of the then-valid first-place votes. If it has not already been decided by one candidate receiving a majority of the votes in an earlier round, this process must eventually lead to a twocandidate contest and thus a clear winner. RCV makes it easier 
for voters to express their true preferences without being concerned about whether their vote will be wasted on a candidate who has no real chance of winning; therefore, we might think that RCV would encourage turnout by minority-party voters. Of course, the counterfactual evaluation of any rule-change effect requires a note of caution. It would not only be changes in turnout levels affected by a shift to RCV; the consequences of a general elections. However, whether any given minor-party candidate will take votes from major-party candidates in a way that benefits the Democrats as opposed to the Republicans depends on the nature of the candidate and the particular circumstances at the time. The appeal of RCV should not depend on expectation of partisan gain because, in the long run, RCV is neutral. ${ }^{14}$ As noted previously, RCV largely eliminates the prob-

\section{What might have happened in 2020 had RCV been used instead of plurality?}

change in electoral rules include different incentives for candidate entry, strategic voting in the mass electorate, and different campaign strategies. For instance, a Trump candidacy might have been less (or more) likely in 2016 if RCV had been in place for the Republican primary. The set of competitors might have been different and the outcome very well may have been affected. Under a different voting rule, calculations about whether to enter the race would have changed. Some of Trump's rivals in 2016 might have defeated him in head-to-head competition at the end of an RCV process, or there might have been more incentives for lem of spoilers while still encouraging the participation of minority-party voters.

Nevertheless, it is useful to remember that no reform comes without unintended consequences. This article demonstrates that it was Trump who was more likely to have been harmed by thirdparty candidates in 2016-and especially in 2020-than his Democratic opponent. It would be ironic, indeed, if a reform supported by liberals and adopted in cities such as San Francisco and New York for local elections resulted in a Trump restoration if it were used to elect a president in 2024.

\section{The appeal of $R C V$ should not depend on expectation of partisan gain because, in the long run, $R C V$ is neutral.}

candidates to seek support from their rivals that would have changed who was eliminated when. ${ }^{12}$ In 2020 , because the two major parties received the majority of the votes cast, it would have been the voters who had selected a minor-party candidate as their first choice who would have their second (or third) choice counted in the final round. Is it plausible to assume that the Jorgensen vote would have gone disproportionately to Trump under RCV? The answer is yes-at least using the 2016 estimates of Libertarian voting behavior from Devine and Kopko (2021) as our guide.

Let us assume that the same set of voters vote in our hypothetical 2020 RCV election-that is, there are no abstentions because their preferred candidates are on the ballot. We further assume that minor-party supporters vote in the manner posited by Devine and Kopko (2021), with those who do vote providing a ranking to at least their top two candidates. Of course, these are strong assumptions, but two states would flip to Trump under RCV even if as many as $50 \%$ of the minor-party candidate voters "undervote." ${ }^{13}$ Although the use of RCV rather than plurality could be expected to have changed the nature of the campaigning and thus the ultimate vote distribution, it still is not unreasonable to believe that had the 2020 election been held under RCV, Trump would have captured two states that in fact he lost and come within 11 votes of an Electoral College victory. Therefore, based on this analysis and in looking forward to a potential 2024 third presidential campaign, Trump should be seriously concerned about a Libertarian spoiler. Given this distinct possibility, he should be a strong supporter of RCV being used in 2024 because it will mitigate the spoiler effect-and the same is potentially true for any Republican presidential candidate in 2024.

Opposition to RCV from the political right is rooted in the idea that liberals would benefit from such a reform, especially in

\section{ACKNOWLEDGMENTS}

The authors thank Elsie Goren and Anjali Akula for excellent research assistance. We also thank Christopher Devine and Kyle Kopko for sharing an early draft of their paper. We have benefited greatly from the comments of the two editors and the three reviewers who, in addition to helping improve the article, saved us embarrassment by alerting us to unforgiveable errors in our numbers. We extend further gratitude to the copyeditor for improving this manuscript. Grofman's involvement was supported by the Jack W. Peltason Chair at the University of California, Irvine. "

\section{NOTES}

1. Referring to this method as "ranked-choice" voting is a misnomer because there are many methods (e.g., the Borda Rule and other scoring rules) that require voters to rank ballots (Grofman and Feld 2004; Grofman, Feld, and Fraenkel 2017). RCV is known as the "alternative vote" when used in countries such as Australia and Fiji (Fraenkel and Grofman 2006, 2007). It previously was labeled as an "instant runoff" by US reformers because it allows for an elimination process that otherwise would require multiple elections.

2. The Alaska variant, a top-four primary, is different from the rules for RCV in Maine.

3. Similarly, although there are circumstances in which RCV will foster more moderate candidates than plurality voting, it is not guaranteed (Grofman and Feld 2004). Expectations are affected by the nature of the party system, the number of candidates and their ideological distribution, and-especiallywhether RCV is being used in a primary, general, or nonpartisan election. For example, there is evidence that Democratic voters would give a slight edge to moderate candidates in a pairwise contest between a Democrat and Trump (Broockman and Kalla 2021). However, there remains the issue of whether moderate candidates with substantial later-round support still might be eliminated in earlier phases of RCV balloting.

4. In a 2020 op-ed for USA Today, former Libertarian vice presidential candidate Bill Weld and 2021 candidate for mayor of New York City Andrew Yang advocated a switch to RCV in presidential primaries (Yang and Weld 2020). (New York City used RCV for its Democratic mayoral race for the first time in 2021). 
5. Evan McMullin won an additional 731,991 votes, 243,690 of which were cast in Utah. He was considered the alternative to Trump in that state and he received a significant $22 \%$ of all Utah votes; however, Trump was able to win Utah by more than 200,000 votes. Election results are available at www.fec.gov/resources/cmscontent/documents/federalelections2016.pdf.

6. There is good reason to think that a Libertarian candidate would be the obvious second choice of Republican voters, or vice versa, but as Devine and Kopko (2021) show, nontrivial percentages of Libertarian voters would vote for the Democrat over the Republican. This likely is determined by whether voters place more salience on economic or social issues. Libertarians do not fall neatly on a onedimensional line of ideology.

7. Federal Elections Commission data for the 2016 and 2020 elections are available at www.fec.gov/resources/cms-content/documents/federalelections2016.pdf and www.fec.gov/resources/cms-content/documents/202opresgeresults.pdf. Other sources may report slightly different numbers.

8. In only four congressional elections in 2020 was the Libertarian vote larger than the margin of victory: Iowa 3, New York 2, Texas 24, and Utah 4. The Green Party candidate never exceeded the margin of victory in any 2020 House contest.

9. Devine and Kopko (2021) specifically advised against extrapolating their results to other elections, but we argue that 2020 had similar circumstances that make such a comparison plausible. For instance, Trump was the Republican nominee in both elections; therefore, concerns about an anti-Trump vote driving the Libertarian ballots apply in both cases. Additionally, at the presidential level, there appear to be fewer split-ticket voters and fewer swing voters (Gelman et al. 2016). Moreover, estimates of the level of abstention based on 2016 are probably conservatively biased because turnout in 2020 was much higher than in 2016 . Indeed, we expect continuing high levels of turnout in 2024, especially if former President Trump is on the ballot.

10. Under this hypothetical scenario, Trump would win 259 electors and Biden 279

11. There was controversy in Pennsylvania about whether to count late-arriving mailin ballots in 2020. Approximately 10,00o ballots arrived by mail after Election Day. Because the votes could not have changed the results, courts decided not to allow them to be counted. Had the election been closer, more scrutiny would have been placed on what to do with these ballots (Lai 2021).

12. In June 2021, "Kathryn Garcia and Andrew Yang-running second and fourth in the13-candidate field, according to a [then] recent Marist Poll-campaigned together in Flushing, Queens, a heavily Asian American stronghold for Mr. Yang, and the Lower East Side of Manhattan, favorable territory for Ms. Garcia" (The Economist 2021).

13. "Undervoting" occurs when some later ranks are left blank (Kilgour, Grégoire, and Foley 2020)

14. We also must be careful about claimed past effects of third-party candidacies at the presidential level. We previously expressed skepticism about the perception that Jill Stein cost Hillary Clinton the 2016 election. In 1992, Ross Perot's Reform Party candidacy is widely viewed to have taken votes that otherwise would have gone to George H. W. Bush. However, as Lacy and Burden (1999) demonstrated, Perot increased overall turnout and reduced Clinton's vote, contrary to popular perception. Similarly, there is debate about which party benefited most from the George Wallace candidacy. Stockton and Wayman (1983) demonstrated that, even in the Midwest-in Dearborn, Michigan-many Wallace voters eventually became Republicans and already were moving in that direction in 1968.

\section{REFERENCES}

Abramowitz, Alan I., and Steven W. Webster. 2018. "Negative Partisanship: Why Americans Dislike Parties but Behave Like Rabid Partisans." Political Psychology 39 (S1): 119-35. https://doi.org/10.1111/pops.12479.

Akula, Anjali, Jonathan Cervas, and Elsie Goren. 2020. "Great Lobster and a More Equitable Voting System Exists in Maine.” 3Streams, November 2. https:// medium.com/3streams/a-more-equitable-voting-system-in-maine-rankedchoice-voting-864cb3367468.

Broockman, David, and Joshua Kalla. 2021. "Candidate Ideology and Vote Choice in the 2020 US Presidential Election." OSF Preprints, February 25. DOI:10.31219/osf io/25wm9.

Burden, Barry C., David T. Canon, Kenneth R. Mayer, and Donald P. Moynihan. 2014. "Election Laws, Mobilization, and Turnout: The Unanticipated Consequences of Election Reform." American Journal of Political Science 58 (1): 95-109. http:// doi.wiley.com/10.1111/ajps.12063.

Cervas, Jonathan R., and Bernard Grofman. 2019. "Are Presidential Inversions Inevitable? Comparing Eight Counterfactual Rules for Electing the U.S. President." Social Science Quarterly 100 (4): 1322-42. https:// onlinelibrary.wiley.com/doi/abs/10.1111/ssqu.12634.

Devine, Christopher J., and Kyle C. Kopko. 2016. "5 Things You Need to Know about How Third-Party Candidates Did in 2016.” Washington Post, November 16. www.washingtonpost.com/news/monkey-cage/wp/2016/11/15/5-things-youneed-to-know-about-how-third-party-candidates-did-in-2016.

Devine, Christopher J., and Kyle C. Kopko. 2021. "Did Gary Johnson and Jill Stein Cost Hillary Clinton the Presidency?" The Forum 19(2): 173-201. https:// www.degruyter.com/document/doi/10.1515/for-2021-0011/html.
Foley, Edward B. 2020. Presidential Elections and Majority Rule: The Rise, Demise, and Potential Restoration of the Jeffersonian Electoral College. Oxford: Oxford University Press.

Fraenkel, Jon, and Bernard Grofman. 2006. "Does the Alternative Vote Foster Moderation in Ethnically Divided Societies? The Case of Fiji." Comparative Political Studies 39 (5): 623-51. https://doi.org/10.1177/0010414005285032.

Fraenkel, Jon, and Bernard Grofman. 2007. "The Merits of Neo-Downsian Modeling of the Alternative Vote: A Reply to Horowitz.” Public Choice 133 (1-2) 1-11.

Gelman, Andrew, Sharad Goel, Douglas Rivers, and David Rothschild. 2016. "The Mythical Swing Voter." Quarterly Journal of Political Science 11 (1): 103-30. http:// dx.doi.org/10.1561/100.00015031_supp.

Grofman, Bernard, and Jonathan R. Cervas. 2018. "Can State Courts Cure Partisan Gerrymandering: Lessons from League of Women Voters v. Commonwealth of Pennsylvania (2018)." Election Law Journal: Rules, Politics, and Policy 17 (4): 264-85. www.liebertpub.com.

Grofman, Bernard, and Scott L. Feld. 2004. "If You Like the Alternative Vote (a.k.a. the Instant Runoff), Then You Ought to Know about the Coombs Rule." Electoral Studies 23 (4): 641-59. https://linkinghub.elsevier.com/retrieve/pii/ So2613794030006oX.

Grofman, Bernard, Scott L. Feld, and Jon Fraenkel. 2017. "Finding the Threshold of Exclusion for All Single-Seat and Multi-Seat Scoring Rules: Illustrated by Results for the Borda and Dowdall Rules." Mathematical Social Sciences 85:52-56. www.sciencedirect.com/science/article/pii/So16548961630172X.

Grose, Christian R. 2020. "Reducing Legislative Polarization: Top-Two and Open Primaries Are Associated with More Moderate Legislators." Journal of Political Institutions and Political Economy 1 (2): 267-87. www.nowpublishers.com/article Details/PIP-0012.

Herron, Michael C., and Jeffrey B. Lewis. 2007. "Did Ralph Nader Spoil Al Gore's Presidential Bid? A Ballot-Level Study of Green and Reform Party Voters in the 2000 Presidential Election." Quarterly Journal of Political Science 2 (3): 205-26. www.nowpublishers.com/article/Details/QJPS-5039.

John, Sarah, Haley Smith, and Elizabeth Zack. 2018. "The Alternative Vote: Do Changes in Single-Member Voting Systems Affect Descriptive Representation of Women and Minorities?" Electoral Studies 54 (April): 90-102. https:// doi.org/10.1016/j.electstud.2018.05.009.

Kilgour, D. Marc, Jean Charles Grégoire, and Angèle M. Foley. 2020. "The Prevalence and Consequences of Ballot Truncation in Ranked-Choice Elections." Public Choice 184 (1-2): 197-218. https://doi.org/10.1007/s11127-019-00723-2.

Lacy, Dean, and Barry C. Burden. 1999. "The Vote-Stealing and Turnout Effects of Ross Perot in the 1992 U.S. Presidential Election." American Journal of Political Science 43 (1): 233. www.jstor.org/stable/2991792?origin=crossref.

Lai, Jonathan. 2021. "Pennsylvania Still Struggling to Get Mail-In Voting Deadline under Control." The Philadelphia Inquirer, March 21. www.post-gazette.com/ news/politics-state/2021/03/21/Pennsylvania-still-struggling-to-get-mail-invoting-deadlines-under-control/stories/202103210082.

Magee, Christopher S. P. 2003. "Third-Party Candidates and the 2000 Presidential Election.” Social Science Quarterly 84 (3): 574-95. http://doi.wiley.com/10.1111/ 1540-6237.8403006

Maine Examiner. 2019. "Poliquin Calls Ranked-Choice Voting a 'Rip Off' in Testimony to the Massachusetts Legislature." November 12. https:// maineexaminer.com/poliquin-calls-ranked-choice-voting-a-rip-off-in-testimonyto-massachusetts-legislature.

McGhee, Eric, Seth Masket, Boris Shor, Steven Rogers, and Nolan McCarty. 2014. "A Primary Cause of Partisanship? Nomination Systems and Legislator Ideology." American Journal of Political Science 58 (2): 337-51. http://doi.wiley.com/10.1111/ ajps.12070.

Nagle, John F. 2019. "What Criteria Should Be Used for Redistricting Reform?" Election Law Journal: Rules, Politics, and Policy 18 (1): 63-77. www.liebertpub.com/ doi/10.1089/elj.2018.0514.

Nguyen, Tina. 2016. "Gary Johnson and Jill Stein Handed the Presidency to Donald Trump.” Vanity Fair. www.vanityfair.com/news/2016/11/gary-johnson-jill-steinelection-2016.

Pathé, Simone. 2018. "Maine's Bruce Poliquin Loses in Ranked-Choice Voting." Roll Call, November 15. www.rollcall.com/2018/11/15/maines-bruce-poliquin-loses-inranked-choice-voting.

Saxon, James. 2020. "Reviving Legislative Avenues for Gerrymandering Reform with a Flexible, Automated Tool." Political Analysis 28 (3): 1-23. www.cambridge.org/ core/product/identifier/S1047198719000457/type/journal_article.

Stockton, Ronald R., and Frank Whelon Wayman. 1983. A Time of Turmoil: Values and Voting in the 1970's. East Lansing: Michigan State University Press.

The Economist. 2021. "Democrats in New York Choose a Mayoral Candidate in a Tight Race: Besides the Candidates, Ranked-Choice Voting Is on Trial.” June 21. www.economist.com/united-states/2021/06/21/democrats-in-new-york-choose-amayoral-candidate-in-a-tight-race. 
United States District Court District of Maine. 2018. Baber v. Dunlap, 376 F. Supp. 3d 125, 143 (D. Me. 2018).

Wang, Samuel, Jonathan Cervas, Bernard Grofman, and Keena Lipsitz. 2021. "A Systems Framework for Remedying Distortions in US Democracy."

Social Science Research Network Electronic Journal. www.ssrn.com/abstract= 3800433 .
Wuffle, A. 1986. "Reflections on Academia." PS: Political Science \& Politics 19 (1): 57 https://www.jstor.org/stable/419291?origin=crossref.

Yang, Andrew, and Bill Weld. 2020. "Why Ranked-Choice Voting Will Improve America's Elections.” USA Today, October 2. www.usatoday.com/story/opinion/ 2020/10/02/why-ranked-choice-voting-improve-american-elections-yang-weldcolumn/5877731002. 